\title{
Improving self-esteem of muscular men by posting shirtless photos on Instagram
}

\author{
Nobertus Ribut Santoso \\ Communication Department \\ Faculty of Social and Political Sciences \\ Universitas Atma Jaya Yogyakarta \\ Yogyakarta, Indonesia \\ nobertus_ribut@staff.uajy.ac.id
}

\begin{abstract}
This research investigate how muscular men improve their self-esteem by posting shirtless photos on Instagram. Data are gathered by conducting interview with three muscular men who regularly post their shirtless pictures on the Instagram. The data are analyzed by using thematic analysis. Building a muscular body and posting their shirtless pictures that show their proportional, symmetrical, and muscular body on Instragram can develop their self-esteem since their followers become respect on them shown by giving loves and comments on the shirtless pictures they post.
\end{abstract}

Keywords—self-esteem; muscular men; Instagram

\section{INTRODUCTION}

A recent study by Hootsuite [1] describes Indonesia as one of the countries with the highest rate of population that access the internet on the frequent basic. With the total population of about 250 million, Indonesian internet users have reached 139 million people. As many as 130 million people have access to social media. These numbers mean, social media users in Indonesia have reached $97.96 \%$ of the total population who have the access to the Internet.

This study also shows that YouTube is the most visited website in Indonesia, with Facebook in the second rank, and Instagram sits in the third rank. Instagram users in Indonesia have reached 53 million users. The number of Instagram users if grouped by gender categories shows that $49 \%$ of Instagram users in Indonesia are female and $51 \%$ male. More comprehensive findings are shown by TNS, one of the survey institutions in the UK which in 2015 also conducted research on Intagram users in Indonesia [2]. Their study finds that as many as 59\% of Instagram users in Indonesia are young people aged between 18 and 24 years who are well-educated from the middle class family background. They also find that as many as $88 \%$ of Instagram users in Indonesia apply existing filters in the platform, while $97 \%$ of users always write information to be searched through search feature owned by Instagram to get more specific information. In addition, as many as $97 \%$ of Instagram users in Indonesia write comments and tag their friends to encourage the search process on Instagram.
Photos and videos are the main contents on Instagram. These contents distributed on Instagram includes 'selfies', food, luxurious items, family photos and videos, special events, pets, outdoors, travel photos, quotes or memes, and photos or videos found online [2]. In this case, interesting content is more attractive to potential followers on Instagram. Since the number of followers matters on Instagram, Instagram users would employ creative strategies to increase the number of their followers. Starting from buying followers from certain third-party service providers, harmonising their contents, making neat contents, using their sexual appeal or body image are used to attract more followers.

TNS's study also finds that both men and women are trying to present the most attractive figure of themselves on their Instagram posts [2]. The objectification on Instagram then began to appear with accounts aimed at collecting beautiful and handsome faces, which is highly popular amongst college students' Instagram accounts. From a previous observation (2018), almost every university in Indonesia has an account for such purposes. For example, Instagram account named @ugmcantik which has the number of followers reached 108,000. Then the account named @uiicantikganteng has 35.7 thousand followers. Instagram account named @ui.cantik has 236,000 followers.

This trend of the increasing number of Instagram accounts that grlorify the objectification if both women and men sexual appeal is supported by the increasing phenomenon of narcissism on Instagram. Narcissism refers to need of contenment from egotistic admiration of one self. The nature is concerned with status, physical appearance, popularity in society, and intelligence [3]. In a study conducted by Swinburne University finds that there are two types of narcissism among Instagram users, which are grandiose and vulnerable narcissism. Grandiose narcissism is the kind of narcissism that many people are familiar with. This kind of narcism is characterised with flamboyant, assertive, and dominant behaviours. People who carry this kind of narcism tend to be over-confident in making decisions and often fail to learn from mistakes [4]. While the vulnerable narcissism is the opposite, the people under this category tend to fear a rejection. Although these two narcissistic types are the 
opposite, they both share a common goal; they have the need of contenment from egotistic admiration of their own selves.

The combination of narcissismm phenomena that occurs on Instagram, combined with the emergence of accounts that objectify the body have emerged another trend on Instagram. Not just using attractive faces, now many Instagram accounts showing off beautiful bodies. Like Instagram account named @cowoknusantara which has a count of 71.3 thousand followers routinely upload photos of bare-chested men with muscular and athletic body shapes. An Instagram account named@ indomuscle88 which has a number of 198 thousand followers. These two accounts as well as other similar accounts collecting various photos of muscly men and then upload them and credit the Instagram account owners of the photos. With so many followers, making anyone whose photos are uploaded has the chance to grow the follower number. So often these accounts apply the price for each post. Account named @indomuscle88, for example, based on the interview of one of the Instagram users named @rocky_takao97 who once contacted the account @indomuscle88 related procedures to be done so that his picture can be uploaded, he was asked to pay as much as IDR 10,000, - for each post

The presumption that body building is a new trend may have increased because the current access to such kind of information is very easy nowadays. If at the beginning of the appearance of a solid body image can only be accessed through advertisements in magazines, then now these images are everywhere, especially with the new media which is the interaction between humans with computers and the internet, including through websites, blogs, online social media, and online forums.

Instagram brings a great influence on the social life of the society. This can be seen from the number of Instagram users who feel that it is important to expose their 'self' to others by sharing their photos to followers to be acknowledged. The number of followers on Instagram becomes a boost for confidence and it fosters the notion that one's self is important. Any activity that one does is instantly shared with their followers. Reciprocity that occurs through the interaction whether comments, direct messages or just give a 'love', makes a person feel that they are not alone.

The description of the phenomenon above has a big role in one's life, especially on their psychological condition. Abraham Maslow who is famous for his hierarchical theory says that humans have basic needs. Interaction and behavior that occur in Instagram can be regarded as one of the needs that must be fulfilled for self-actualization. The supports provided by followers on Instagram have some physcological impacts on one's level of self-esteem. According to Maslow, self-esteem is a human need that requires fulfillment or satisfaction to proceed to a higher level of need [5].

\section{SOCIAL MEDIA AND SELF-ESTEEM}

A research conducted by Jan, Soomro, and Nawaz [6] shows that social media has a strong relationship with selfesteem. This finding is supported by Smith-Duff [7] that states social media has a big impact on people's lives since they use this media to enhance their self-esteem levels. People who have low self-esteem spend their time to post their information on their social media account in order to boost social selfesteem.

Instragram, one of social media platforms, has an impact on improving self-esteem. Hill and Denman [8] notes people try enhancing their self-esteem by posting their provocative, goofy, or serious pictures on Instagram. The provocative pictures mean the Instagram users must have a significant amount of skin showing, the focus of the picture should show their private parts of the body, and their facial expression should be sexual. The goofy photos are defined as laughing facial expression while serious pictures mean individuals are not smiling or making any kind of blank or straight expression.

Instagram users who upload their pictures have the need to be appreciated by their followers and it will become a cycle. The process of shooting and uploading afterwards is a form of self-expression. After that, they will expect for loves and comments, which to some extent could be incorporated into those accounts that objectify one's body to get many followers and later these photos could increase the possibility of increasing the number of one's followers. At the end of the day, one will assume that they are important and the process will continue to recur.

\section{METHOD}

This research employs qualitative descriptive method for it aims to describe the phenomenon of social life [9]. Data are gathered by conducting interview with three muscular men who regularly post their shirtless pictures on the Instagram. The data are analyzed by using thematic analysis by identifying the main themes summarizing all the views. Steps of thematic analysis are: 1) read and annotate transcripts, 2) identify themes, developing a coding scheme, and 4) coding the data [9].

\section{RESULT AND DISCUSSION}

As social human beings, people cannot live without other people. Therefore, they need to communicate each other. Communication plays important roles since it is functioned to share information, comments, ask questions, express wants and needs, and develop social relationship. By communicating, problems can be solved. This occurred on the participants, by communicating their muscular body through Instagram, feeling of having low self-esteem can be improved.

Diana K. Ivy and Phil Backlund define communication is a continuous and dynamic process in sending and exchanging messages to achieve goals. Additionally, if the communication is defined as a process, Lasswell gives a good way to understand by answering the following questions; who said, what was said, in what channel it was said, to whom it was said, and with what effect it was said [10]. The participants, as communicators communicate their achievement in building 
their body to their followers through Instagram in order to raise their self-esteem. The process of sending the messages is dynamic. They are not only posting their shirtless pictures but they also evaluate themselves based on the feedbacks given by their followers in order to get satisfaction.

Before having a muscular body, the participants have low self-esteem because they feel poorly about themselves and judge themselves to be inferior to others. They were not confidence because they are thin. They feel difficult to find an appropriate cloth. One of the participants was bullied for being skinny and short. This condition encourages him to improve his self-esteem by building his body.

The participants noted that having a muscular body is worth it. However, they noted that building a proportional body needs discipline efforts. Participants have struggled to have a symmetrical and muscular body. They wonder to build a strong and powerful body looked incredibly from every angle in order to achieve an aesthetic body is not easy as they think. Therefore, they take a special kind of training with the purpose of looking better and having more impressive physique. This means that they are motivated to fulfill their personal goals of having the body they dream of.

To get and keep the aesthetic body, the participants try balancing their life by doing exercise, eating healthier food, and having a healthier lifestyle since they assume that the body is an investment for their future. Moreover, they also undertake that getting an ideal body is essential by balancing between the height and weight. By having a proportional, symmetrical, and muscular body, they become more confidence for people will respect on them. Getting respect from other people because of having muscular body can improve the participants' self-esteem since it can make them more satisfied [5]. Moreover, it will also increase their chances of attracting people into their lives.

It is not only about getting respect from other people, another reason the participants desire to build a strong, muscular, and ideal body is an ambition to join a body contest. By showing their body on the body contest, they want to speak to others about their achievement. These two reasons can raise their self-esteem by improving their power. Coopersmith [5] notes power is the ability of someone to influence and control others. Therefore, getting respects and recognition from others give a sense of power since the participants feel that their ambition of getting a muscular body can be achieved satisfactorily. Moreover, they can also earn money by having this body since people trust them as a personal trainer at a commercial gym.

The participants have the power to control themselves in taking action to improve their self-esteem by building their body although it is difficult at the beginning. The first, it is hard to be committed to build self discipline to exercise because they have other activities such as working and studying. The next, consuming food to build and maintain their muscular body costs expensive and it is tasteless. The last, the participants should also spend much money to buy supplements for accelerating their muscle growth.
Improving self-esteem by building a muscular body is problematic. The participants once got frustrated because they have to eat healthy food in order to increase their weight and also to gain muscle mass although they get full. Moreover, it seems there is no result in the beginning about six months while they have efforts to do heavy exercise regularly. However, the families of the participants support them to make trying to get a muscular body. This support can develop their self-esteem since they get significance. Coopersmith [5] states significance is a feeling of being loved and cared about. At home, their family provide nutrition food for getting optimal results in building their body. Moreover, another caring of the family shown by giving the participants extra money to buy chicken breasts containing more protein.

After having a muscular body, their self-esteem has improved significantly for the participants have a competence in achieving their goal [5]. Therefore, the participants feel more confidence and people see them more impressive. Their friends now love having talks with them and their relationship becomes happier. Likewise, they become a credible informant to be asked about healthy food and life.

The use of social media, especially Instagram, continues to grow particularly for adolescents and young adults because they spend most of their life connected to Instagram. Therefore, following the crowd becomes a reason for the participants to make Instagram account for Instagram is accessible and free. People do not have to pay to access it. Moreover, people can easily access without having certain skills and knowledge [11]. Since it is easy to operate, the participants love posting their shirtless pictures showing their muscular body and proportional muscle mass. By posting these pictures, they want to show off their body. Psychologically, it is natural since their body symbolizes the powerful men who can attract their targeted persons. They assume that their shirtless pictures talk a thousand words. It can describe about their body completely. Moreover, they invariably showcase it to demonstrate their macho-ism. Another reason is seeking validation from their followers. All comments and suggestions from their followers become a motivation and encouragement for them to improve building their body. Additionally, after working hard to make their body muscular, they expect their dedication to be seen and noticed by their followers. The last reason is earning some money by selling supplement products or becoming a personal trainer for gym exercise.

Since people use new media, especially social media, delivering messages convey to others in a virtual mode because people live in the virtual world. As a platform of social media, Instagram becomes the hottest buzz among the youths. This platform also provides opportunities for selfrepresentation. Moreover, the participants noted that this social media is the great medium for fun by sharing their shirtless photos. By producing shirtless photos that have a different emotional overlay, the participants convey these photos virtually on Instagram in order to make them proud of themselves. On the other hand, they become a role model because of their muscular body. After posting their shirtless 
pictures, some males consult to them about building the body. If they feel comfortable with the participants, they purpose the participants to be their personal trainers. Getting trust from others can confidently improve their self-esteem.

On the other side, since the photo becomes the main message on the Instagram, the participants are willing to upload the best pictures to be seen to their followers. It takes more than five times to take their shirtless pictures. They will select the best pictures that show their proportional, symmetrical, and muscular body. After posting these pictures, they will check how many loves given by their followers. The more love the participants get from their followers, the more satisfaction they feel. Moreover, they assume that the love becomes an indication that the followers love their pictures. The love also becomes a motivation for them to be better in building their body in order to give an influence to other males to build their body.

Based on the activities the participants regularly do on the Instagram, it can be seen that this platform stimulates narcissistic trends by encouraging them to upload their shirtless pictures frequently in most positive ways. The activity of uploading these photos can strengthen their sense of self-importance to be favorable to others by gaining attention from their followers. This means that Instagram, like other social media, has significant effects on the self-esteem of its users [12].

By using the communication privacy management theory (Petronio in [8]) explaining the process of revealing information, including how and when people choose to share certain information, it helps explaining why the participants love posting their shirtless photos. They feel comfortable sharing types of the photos in order to create a positive impression. By disclosing their pictures to their followers, they have more opportunity to get positive feedbacks.

\section{CONCLUSION}

Posting shirtless photos showing the muscular body on Instagram can improve the self-esteem of the muscular men because people become more respect on them. In this case, they want to create positive impression by sharing their shirtless pictures and they can evaluate themselves based on the feedbacks given by their followers seen from the loves and comments given. Those loves and comments become a motivation and encouragements for them to improve building their body in order to make them more confidence and people seem them more impressive. In taking photos before uploading on the Instagram, it can take more than five times. They will select the best photos showing their proportional, symmetrical, and muscular body looked incredibly from every angle.

\section{REFERENCES}

[1] We Are Social and Hootsuite, "Digital in 2018 in South-East Asia," 2018. [Online]. Available: https://www.slideshare.net/wearesocial/digital-in-2018-in-southeastasia-part-2-southeast-86866464.

[2] Y. Edwin, "Instagram beberkan fakta-fakta pengguna di Indonesia [Instagram Shares Indonesian User Facts],” January 15, 2016, Beritagar.id.

[3] W. K. Campbell, E. A. Rudich, and C. Sedikides, "Narcissism, selfesteem, and the positivity of self-views: Two portraits of self-love," Personal. and Soc. Psychol. Bul., pp. 358-368, 2002.

[4] R. E. Riggio, "What is Grandiose Narcissism? Why Does it Matter?" October 23, 2013, Psychology Today. [Online]. Available: https://www.psychologytoday.com/intl/blog/cutting-edgeleadership/201310/what-is-grandiose-narcissism-why-does-it-matter.

[5] S. Coopersmith, The Antecedents of self esteem. San Francisco: W.H. Freemann \& Co., 1967.

[6] M. Jan, S. A. Soomro, and A. Nawaz, "Impact of Social Media on SelfEsteem,” Eur. Scient. J., vol. 13, no. 23, August 2017.

[7] C. Smith-Duff, Facebook use and its relationship with self-esteem, personalities and addictive tendencies, 2012

[8] A. Hill and L. Denman, “Adolescent Self Esteem and Instagram: An Examination of Posting Behaviors,” 2016. [Online]. Available: https://concordia.csp.edu/comjournal/wpcontent/uploads/sites/40/Instagram-paper.pdf.

[9] N. Bricki and J. Green, A guide to using qualitative research methodology, 2007

[10] D. Mulyana, Pengantar Ilmu Komunikasi [Communication Science Introduction]. Bandung: Rosda Karya, 2007.

[11] Taprial, V., \& Kanwar, P. (2012). Understanding social media. Bookboon.

[12] T. A. Somerville, "The effect of social media use on narcissistic behavior,” J. of Undergrad. Res., vol. 25, 2015. 